\title{
THE FAUNA OF THE SO-CALLED DAKOTA FORMATION OF NORTHERN CENTRAL COLORADO AND ITS EQUIVALENT IN SOUTHEASTERN WYOMING.
}

\author{
BУ JoHN B. REeside, Jr.
}

\section{INTRODUCTION.}

This paper describes a small fauna from beds in northern central Colorado that have long been designated the Dakota formation, often with doubt that all the beds so named were really equivalent to the typical Dakota sandstone of eastern Nebraska. The upper part of the equivalent beds in southeastern Wyoming was referred by some writers to the Benton shale and the lower part to the Cloverly formation. This so-called Dakota formation of northern central Colorado and its equivalent in southeastern Wyoming consist of cherty conglomerate, brown quartzose sandstone, and dark shale. The conglomerate is usually at the base of the series and at many localities is overlain by a single shale unit and that in turn by a sandstone. At other localities, however, there are several alternations of sandstone and shale above the basal conglomeratic layer. The fossils described in this paper, except one specimen, were obtained from the shales of the middle part of the formation. The single specimen, an ammonite, came from the uppermost sandstone.

Fossils from the "Dakota formation" of northern Colorado were first recorded by Prof. Junius Henderson, ${ }^{1}$ of the University of Colorado. Henderson states that fossils were found by T. W. Stanton and himself at almost every good exposure of the "medial shales" from a locality 5 miles north of Boulder, Colo., to Owl Canyon, in northern Larimer County, though they were not determinative. $\mathrm{He}$ suggests that the presence of Comanche fossils at Canon City and the persistence of a tripartite division in the "Dakota formation" indicate "that at least part of the medial

\footnotetext{
1 Henderson, Junius, The foothills formations of north-central Colorado: Colorado Geol. Survey First Ann. Rept., pp. 172-176, 1908; The Cretaceous formations of northeastern Colorado and the foothills formations of north-central Colorado: Colorado Geol. Survey Bull. 19, pp. 83-85, 1920.
}

shales and lower sandstone member in the Boulder district and northward may be the time equivalent of the Comanche." The fossils of the northern area are mostly in poor condition and are said to include one or more species of Ostrea, an Inoceramus indistinguishable from I. labiatus Schlotheim, and an Avicula closely related to $A$. linguaeformis Evans and Shumard, though probably not identical.

Mr. Stanton made six collections from as many localities in 1906 and others in 1909 and 1920. In 1907 Prof. Henderson made a collection of which a part was presented by him to the Geological Survey. In 1921 larger collections were made at six localities by W. T. Lee. These later collections have supplied more adequate specimens of most of the species than were contained in the earlier collections and have shown more definitely the relationships of the fossils. All the material in these collections has, through Mr. Stanton's kindness, been in the writer's hands, as well as specimens for comparison from the Washita fauna of southern Colorado, New Mexico, Kansas, and Texas contained in the collections of the Geological Survey.

\section{THE FAUNA AND ITS RELATIONS.}

The fauna of the "middle Dakota shale" of northern Colorado and southern Wyoming includes seven species, of which one is not definitely determinable, three are assigned to new species, and three are assigned to species previously described. The list of species is as follows:

Inoceramus comancheanus Cragin.

Inoceramus bellvuensis Reeside, $\mathrm{n}$. sp.

Pteria salinensis White.

Ostrea larimerensis Reeside, $\mathrm{n}$. sp.

Ostrea noctuensis Reeside, $\mathrm{n}$. sp.

Anchura kiowana Cragin?

Ammonite, undetermined. 
To this list may be added the scales and bones of undetermined fish and also teeth collected near Loveland, Colo., by Prof. Henderson and identified by J. W. Gidley as probably plesiosaurian. ${ }^{2}$ Inoceramus comancheanus, Pteria salinensis, and Anchura kiowana occur in rocks of Washita age in Kansas and other States, and their occurrence in the beds here considered therefore supports a correlation of the "middle Dakota" with the Washita group, although such a correlation, based on a single species each of Inoceramus and Pteria and a somewhat doubtfully identified species of Anchura, has a rather frail foundation. The other species are not very close to any described forms from the Washita group or the Benton shale and have little value in correlation. The absence of such widespread and abundant species as Ostrea quadriplicata Shumard, Gryphaea corrugata Say, Trigonia emoryi Conrad, Pholadomya sanctisabae Roemer, Cardium kansasense Meek, Protocardia multilineata Shumard, Turritella seriatim-granulata Roemer, and Pachydiscus brazoensis (Shumard), which occur in many collections from the Purgatoire formation and its equivalents, ${ }^{3}$ is surprising. There is no feature of the sediments that indicates conditions of deposition in northern Colorado very different from those in southern Colorado - in fact, on the contrary, the sediments of the two areas are so much alike that tentative correlations between them have been based on the similarity. It is difficult to explain why conditions that would permit the existence of Inoceramus comancheanus, Pteria salinensis, and an Anchura very like $A$. kiowana would completely shut out any trace of their usual associates, which are present in southern Colorado, scarcely 200 miles away. Whether these three species were hardier and could endure conditions that completely precluded the existence of the other species can not be determined. The Washita fauna, as shown by Stanton, ${ }^{4}$ suffers a progressive change northwestward from the Tucumcari region of New Mexico and the Cimarron River region of Oklahoma by the disappearance of

\footnotetext{
2 Henderson, Junius, The Cretaceous formations of northeastern Colorado and the foothills formations of north-central Colorado: Colorado Geol. Survey Bull. 19, p. $85,1920$.

${ }^{3}$ Stanton, T. W., The Morrison formation and its relations with the Comanche series and the Dakota formation: Jour. Geology, vol. 13, pp. 657-669, 1905.

${ }^{4}$ Stanton, T. W., idem.
}

one species after another from the faunal assemblage. In the Purgatoire River region of Colorado the fauna lacks a number of Washita species that are prominent at the localities farther southeast. In the Apishapa River region still more species have dropped out of the fauna, and at Canon City only two or three are known. Such a change as this may well account for the paucity of recognized Washita species in northern central Colorado and southeastern Wyoming, though the causes of the change are entirely conjectural. It has been suggested by Stanton ${ }^{5}$ that the difference between the fauna of the Purgatoire formation and that of the so-called Dakota formation of northeastern Colorado is due to a difference in age, the sea in which the Purgatoire formation was deposited not having reached northern Colorado until Dakota time, when many of the characteristic Washita species had ceased to exist. The relationship of the beds of Washita age in Kansas to the overlying Dakota formation is so intimate as to preclude any great difference in age, and the difference in interpretation of the fauna is therefore not very great. However, it seems to the writer that it is better to regard the fossils of the so-called Dakota formation as of the same age as those of the Purgatoire formation and attribute the differences between them to some now unknown difference in the conditions under which the sediments were deposited. The fauna from northern Colorado, in spite of its paucity, is more like that of the Washita group than that of the succeeding Benton shale or that of any known Dakota beds, and a correlation based on the fauna must be a correlation with the Washita rather than with the Benton. The fauna is apparently an extension of the known range of the late Comanche fauna as far north as southern Wyoming.

The single ammonite, Pachydiscus? sp., from the uppermost sandstone of the "Dakota formation," is sufficient only to show that this sandstone is in at least one locality of marine origin. The specimen might belong to the Washita fauna or to a later one. The marine origin of the sandstone at two other localities is indicated by the presence of Halymenites. These localities are at the mouth of Little

${ }_{5}$ Stanton, T. W., Some prob'ems connected with the Dakota sandstone: Geol. Soc. America Bull., vol. 33, pp. 265-272, 1922. 
Thompson Canyon and 10 miles north of Boulder, Boulder County, Colo. ${ }^{6}$

6 Henderson, Junius, The Cretaseous formations of northeastern Colorado and the foothills formations of north-central Colorado: Colorado Geol. Survey Bull. 19, p. 85, 1920.
DISTRIBUTION OF SPECIES.

The following table and list show the geographic distribution of the species described in this paper:

Distribution of species from the so-called Dakota formation of northern central Colorado and southern Wyoming by localities.

\begin{tabular}{|c|c|c|c|c|c|c|c|c|c|c|c|c|c|c|c|c|}
\hline$x^{2}$ & $c 1$ & 2 & 3 & 4 & 5 & 6 & 7. & 8 & 9 & 10 & 11 & 12 & 13 & 14 & 15 & 16 \\
\hline Inoceramus comancheanus Cragin. & X & & & 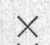 & X & & & & X & x & x & x & & x & X & \\
\hline Inoceramus bellvuensis Reeside... & & & & $\hat{x}$ & $\cdots$ & & & & & & $x$ & & & .. & $\cdots$ & \\
\hline Pteria salinensis White. . . . . & $x$ & $x$ & $x$ & $x$ & 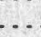 & $x$ & & & & & $\hat{x}$ & $x$ & & & $x$ & $x$ \\
\hline Ostrea larimerensis Reeside. & $\ldots$ & - & $\cdots$ & $\ldots$ & $\therefore$ & $x$ & & & & & $x$ & $\ldots$ & & $x$ & 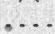 & 2 \\
\hline Ostrea noctuensis Reeside.. & $\cdots$ & $\ldots$ & $\ldots$ & $x$ & $\ldots$ & $x$ & $x$ & $X$ & x & $x$ & $x$ & $\ldots$ & $\ldots$ & - . . & $\cdots$ & \\
\hline Anchura kiowana Cragin?......... & & & $\cdots$ & $\cdots$ & & . & & & & $x$ & $x$ & & & $\ldots$ & $\ldots$ & \\
\hline $\begin{array}{l}\text { Pachydiscus? sp } \ldots \ldots \ldots \ldots \ldots \\
\text { Ammonite, undetermined. } \ldots \ldots \ldots \ldots \ldots\end{array}$ & - & 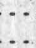 & $\begin{array}{l}\cdots \\
\cdots\end{array}$ & $\cdots$ & $\cdots$ & $\cdots$ & & & & $\cdots$ & $\begin{array}{ll}\cdots \\
\cdots\end{array}$ & ... & $\begin{array}{l}X \\
\ldots\end{array}$ & $\ldots$ & $\ldots$ & $x$ \\
\hline Fish scales and bones............. & $\ldots$ & $x$ & & $\ldots$ & $x$ & $x$ & $x$ & $x$ & x & $x$ & $\ldots$ & $\because$ & $\ldots$ & $x$ & $x$ & $x$ \\
\hline
\end{tabular}

$a$ Numbers refer to the lozalities given in tha following list.

1. U. S. G. S. locality 3689 . Sixmile Canyon, 4 miles north of Boulder, Boulder County, Colo.; sandy shale between the "Dakota" sandstones; T. W. Stanton, collector, 1906:

Inoceramus comancheanus Cragin.

Pteria salinensis White.

Ostrea sp. undetermined.

2. U. S. G. S. locality 3690 . Lykins Gulch, 9 miles north of Boulder, Boulder County, Colo.; sandy shale between the "Dakota" sandstones; T. W. Stanton, collector, 1906:

Pteria salinensis White.

Ostrea sp. undetermined.

Fish remains.

3. U. S. G. S. locality 3685 . South end of Rabbit Mountain, 7 miles northwest of Longmont, Boulder County, Colo.; shales between the "Dakota" sandstones; T. W. Stanton, collector, 1906:

Inoceramus sp. undetermined.

Pteria salinensis White.

Ostrea sp. undetermined.

4. U. S. G. S. locality 3686 . Lykins ranch, at mouth of canyon of Little Thompson Creek, Boulder County, Colo.; sandy shale between the "Dakota" sandstones; T. W. Stanton, collector, 1906:

Inoceramus comancheanus Cragin.

Inoceramus bellvuensis Reeside.

Pteria salinensis White.

Ostrea noctuensis Reeside.

5. U. S. G. S. locality 10631. Handy ditch, canyon west of Loveland, Larimer County, Colo.; sandy shale beneath the "upper Dakota" sandstone; W. T. Lee, collector, 1921:

Inoceramus comancheanus Cragin.

Fish remains.

6. U. S. G. S. locality 10657. Handy ditch, canyon west of Loveland, Larimer County, Colo.; middle of shale between the "Dakota" sandstones; W. T. Lee, collector, 1921.

Inoceramus sp. undetermined.

Pteria salinensis White.

Ostrea larimerensis Reeside.

Ostrea noctuensis Reeside

Fish remains.
\%. U. S. G. S. locality 3688. Eight miles northwest of Loveland and 2 miles north of the junction of Big Thompson and Buckhorn creeks, Larimer County, Colo.; sandy shale between the "Dakota" sandstones; T. W. Stanton, collector, 1906:

Ostrea noctuensis Reeside.

Fish remains.

8. U. S. G. S. locality 10659. Soldier Canyon, west of Fort Collins, Larimer County, Colo.; middle of shale of "middle Dakota"; W. T. Lee, collector, 1921:

Inoceramus comancheanus Cragin.

Pteria salinensis White.

Ostrea larimerensis Reeside.

Ostrea noctuensis Reeside.

Anchura kiowana Cragin?

Fish remains.

9. U. S. G. S. locality 3687. Ditch bank on north side of Cache la Poudre River, 9 miles northwest of Fort Collins and 2 miles above Laporte, Larimer County, Colo.; shale between the "Dakota" hogbacks; T. W. Stanton, collector, 1906.

Inoceramus comancheanus Cragin.

Inoceramus bellvuensis Reeside.

Ostrea larimerensis Reeside.

Ostrea noctuensis Reeside.

Fish remains.

10. U. S. G. S. locality 10660. Ditch on "Dakota" ridge in sec. 12 , T. 8 N., R. $70 \mathrm{~W}$., north of Bellvue, Larimer County, Colo.; upper part of "middle Dakota"; W. T. Lee, collector, 1921:

Inoceramus comancheanus Cragin.

Inoceramus bellvuensis Reeside.

Pteria salinensis White.

Ostrea larimerensis Reeside.

Ostrea noctuensis Reeside.

Anchura kiowana Cragin?

Fish remains.

11. U. S. G. S. locality 5401. Owl Canyon, 12 miles north of Fort Collins, Larimer County, Colo.; "Amiddle Dakota"; Junius Henderson, collector, 1907

Inoceramus comancheanus Cragin.

Inoceramus bellvuensis Reeside.

Pteria salinensis White.

Ostrea larimerensis Reeside. 
Ostrea noctuensis Reeside.

Anchura kiowana Cragin?

12. U. S. G. S. locality 10375. Two miles southeast of Greenacre ranch, 20 miles north of Fort Collins, Larimer County, Colo.; dark shale beneath the "upper Dakota" hogback; T. W. Stanton, collector, 1920:

Inoceramus comancheanus Cragin.

Pteria salinensis White.

13. U. S. G. S. locality 10375 a. Same locality as 10375; upper sandstone of the "Dakota" hogback, above the dark shales; T. W. Stanton, collector, 1920:

Pachydiscus? sp.

14. U. S. G. S. locality 10662. Schoolhouse near Box Elder Creek, southeast of Greenacre ranch, Larimer County, Colo.; upper part of "middle Dakota"; W. T. Lee, collector, 1921:

Inoceramus comancheanus Cragin.

Ostrea larimerensis Reeside.

Fish bone.

15. U. S. G. S. locality 5863. Horse Creek, 30 miles northwest of Cheyenne, Laramie County, Wyo.; shale beneath the upper ledge of the "Dakota"; T. W. Stanton, collector, 1909:

Inoceramus comancheanus Cragin.

Pteria salinensis White.

Gastropod, undetermined.

Fish remains.

16. U. S. G. S. locality 10670. Gap of Chugwater Creek at Iron Mountain, Laramie County, Wyo.; "middle Dakota" shale; W. T. Lee, collector, 1921:

Inoceramus comancheanus Cragin.

Pteria salinensis White.

Ostrea larimerensis Reeside.

Ammonite, undetermined.

Fish remains.

\section{DESCRIPTIONS OF SPECIES.}

\section{Genus INOCERAMUS Sowerby.}

\section{Inoceramus comancheanus Cragin.}

Plate XLV, figures 1-7

1895. Inoceramus comancheana Cragin, Colorado Coll. Studies, 5th year, pp. 53-55.

1901. Inoceramus comancheanus Cragin. Hill, U. S. Geol. Survey Twenty-first Ann. Rept., pt. 7, pl. 35, fig. 4 .

1920. Inoceramus comancheanus Cragin. Adkins and Winton, Texas Univ. Bull. 1945 , p. 73 , pl. 17, fig. 1-3.

Cragin's original description is as follows:

Shell equivalve, broadly and obliquely rhombic-ovate, more gibbous than that of $I$. labiatus Schlotheim, the axis of greatest dimension diverging from the hinge line much more widely than in the latter species; alar outline rounded; anterior margin descending steeply in a nearly straight line for a considerable distance on front of the beaks, then curving rather suddenly away toward the somewhat prominently convex distal part of the basal outline, anterior and posterior margins making nearly a right angle with each other; beaks placed opposite the anterior extremity of the hinge, moderately inflated and moderately elevated above the hinge line, anteriorly flattened but not abruptly so; hinge plate rather short, broad, the ligamental grooves crowded, more numerous and longer than in I. labiatus, though ample and shallow; valves thin, ornamented with numerous concentric riblike folds, which on the distal and ventral parts are quite strongly elevated and much narrower than the intervals between them.

Height 82 , length 95 , breadth 54 , axis of greatest dimension 107 milimeters. In some examples the species attains considerably larger dimensions.

The writer has in hand a number of fairly good specimens of an Inoceramus indistinguishable from specimens of $I$. comancheanus. This species is characterized by its elongate form, the axis of elongation making an angle of $50^{\circ}$ to $70^{\circ}$ with the hinge line; moderately coarse, rounded, concentric ribs without finer sculpture between; ribs somewhat irregular; umbo rather slender; anterior margin straight or slightly concave, making an angle of $70^{\circ}$ to $100^{\circ}$ with the hinge line. It differs from the later I. labiatus, as pointed out by Cragin, in the greater angle between the axis of elongation and the hinge line. It is also less elongated, has stronger sculpture and less smoothly ovate concentric ribs, and lacks the fine striae between the concentric ribs. It somewhat resembles an undescribed species associated with $I$. labiatus and related to $I$. lamarcki var. cuvieri Sowerby, though it differs in having a more elongate form and much finer sculpture. Inoceramus anglicus Woods, of the Gault; $I$. crippsi Mantell, of the Cenomanian; and $I$. pictus Sowerby, of the Cenomanian, are related species. I. anglicus has more regular concentric ribs and a broader curvature and is a wider shell. I. crippsi has a greater angle between the anterior margin and the hinge line $\left(140^{\circ}\right)$, a thicker umbo, and fine striae between the concentric ribs. $I$. pictus differs chiefly in possessing finer sculpture. These comparisons are based largely on figures by Woods ${ }^{7}$ and might not hold in an actual comparison of specimens, but so far as the writer is able to determine, $I$. comancheanus is closer to $I$. crippsi and $I$. pictus than to the other species mentioned.

Occurrence: Many localities in Texas, Kansas, Oklahoma, and southern Colorado. In northern Colorado: Sixmile Canyon, Lykins ranch, canyon west of Loveland, Soldier Canyon, Cache la Poudre River, north of

7 Woods, Henry, A monograph of the Cretaceous Lamellibranchia of England, vol. 2, pt. 7, pp. 264, 273, 279, text figs. 29, 33-36; pl. 45, figs. 8-10; pl. 48, figs. 2, 3; pl. 49, figs. $5,6,1911$. 
Bellvue, Owl Canyon, 2 miles southeast of Greenacre ranch, Boxelder Creek. In Wyoming: Horse Creek and Iron Mountain. ${ }^{8}$

Inoceramus bellvuensis Reeside, n. sp.

Plate XLVI, figures 1-3.

Shell apparently equivalve, very inequilateral. Outline of valve subquadrate; anterior part moderately convex; posterior part flattened, forming an ill-defined wing dorsally. Anterior margin nearly straight; ventral margin broadly convex; posterior margin nearly straight. Anterior margin makes an angle of $120^{\circ}$ with the hinge line. Small part of hinge line preserved shows ligament pits small and shallow. Umbones nearly terminal. Ornamentation of somewhat irregular narrow concentric ribs with unsymmetrical curvature; interspaces wider than ribs, concave.

This species is marked by its broad subquadrate valves, small convexity, and sculpture. It is perhaps closer to Inoceramus crippsi Mantell than to any other species but shows no trace of the fine striae between the ribs that are present on that species.

The specific name is derived from Bellvue, Colo., near which the type was collected.

Occurrence: Lykins ranch, Cache la Poudre River, north of Bellvue, and Owl Canyon, Colo.

\section{Genus PTERIA Scopoli.}

\section{Pteria salinensis White.}

Plate XLVII, figures 1-5.

1880. Pteria (Oxytoma) salinensis White, U. S. Nat. Mus. Proc., vol. 2, pt. 2, pp. 296, 297, pl. 5, figs. 1, 2.

1883. Pteria (Oxytoma) salinensis White, U. S. Geol. and Geog. Survey Terr. Twelfth Ann. Rept., pt. 1 pp. 15,16 , pl. 16 , figs. $2 \mathrm{a}$, b.

11893. Pteria salinensis White. Cragin, Texas Geol. Survey Fourth Ann. Rept., p. 211.

White's original description is as follows:

Shell rather large for a Cretaceous Pteria; the body, exclusive of the wings, obliquely subovate, broad at the base, moderately gibbous, distinctly but not very greatly inequivalve; the left valve, as usual, more convex than the right and its beak more prominent; the convexity of the valves somewhat uniform but increasing toward the umbonal region in each, where it is greatest; anterior wing moderately large, defined from the body of the shell by being laterally compressed but not by any distinct auricular furrow, the byssal sinus under the anterior wing of the right valve having the usual size and shape common

8 The full desription of all these localities is given on pages - to Oxytoma; posterior wing not proportionately large and not distinctly defined from the body of the shell except by a somewhat gradual lateral compression; its posterior angle not greatly produced; hinge line less than the axial length of the shell; posterior adductor scars not distinct; anterior adductor scars distinct and deep for a shell of this genus, placed immediately in front of the beaks, that of the left valve being more distinct than the other. ***

It is known to have reached an axial length of more than 60 millimeters, a transverse width near its base of at least 50 millimeters, and a thickness of about 25 millimeters when both valves were in natural position.

The character of the surface is not known, but it was evidently nearly smooth, as is usual with Oxytoma.

The writer has in hand a number of specimens that include both valves of a smoothshelled Pteria. Such simple shells are somewhat unsatisfactory material for comparisons, as very similar species occur at a number of very distinct horizons, from the Paleozoic on. However, in comparison with species from the Washita, Colorado, and Montana groups the specimens in hand are so close to $P$. salinensis that it is difficult to pick out an essential difference. $P$. gastrodes (Meek) of the Benton is a large, stout, nearly equivalve shell with the outline of the valves well rounded, the anterior ear short proportionately, and the axis of the shell only moderately oblique. $P$. linguaeformis (Evans and Shumard) is a proportionately small, inequivalve shell, with valves rather elongated and oblique, and the anterior ear small. $P$. satinensis has a less elongated form than $P$.linguaeformis and is much larger, but it is not nearly so stout and rounded as $P$. gastrodes. It has also a relatively long and narrow anterior ear and is nearly equivalve.

Occurrence: Washita group of Texas and rocks of same age in Kansas and southern Colorado. In northern Colorado: Sixmile Canyon, Lykins Gulch, Lykins ranch, south end of Rabbit Mountain, canyon west of Loveland, Soldier Canyon, north of Bellvue, Owl Canyon, and 2 miles southeast of Greenacre ranch. In Wyoming: Horse Creek and Iron Mountain.

\section{Genus OSTREA Linnaeus.}

Ostrea larimerensis Reeside, n. sø.

Plate XLVII, figures 6-12.

Shell very thin, flattened, acutely triangular in outline; small, an average specimen attaining a length of 60 millimeters. Beak narrowly tapered; base of valve smoothly rounded. 
Margins of the valves smooth. Surface irregularly and finely wrinkled, especially near the beak. Internal cast reflects the larger wrinkles, but otherwise smooth. Hinge not seen; probably small and weakly developed.

The writer has hesitated to apply names to this and the following species of Ostrea. Both belong to a type of simple oyster that appears in many faunas from Jurassic to Recent time, and although differences may be pointed out the variability of the shells is so great that no differences seem to hold good, and separation into species is more or less arbitrary. However, there appear to be no described forms in the equivalent or adjacent faunas of the region that may be compared with these, and as a matter of convenience names are here applied.

The specific name of $O$. larimerensis is derived from Larimer County, Colo.

Occurrence: Canyon west of Loveland, Soldier Canyon, Cache la Poudre River, north of Bellvue, Owl Canyon, and Box Elder Creek, Colo.; Iron Mountain, Wyo.

\section{Ostrea noctuensis Reeside, n. sp.}

Plate XLVIII, figures 1-5.

Shell very thin, gently arched, subquadrate, of medium size, an average individual attaining a length of 80 or 90 millimeters. Beak bluntly rounded, basal part of shell broadly rounded. Margins of valves smooth. Surface of most of the specimens marked by fine, rather regular concentric lines and a few broad, obscure folds. Surface of other specimens irregularly wrinkled, much as in $O$. larimerensis. Internal cast smooth except for the reflection of the broad folds. Hinge small and weak.

This species may possibly be cilly a variant of 0 . larimerensis, as it is of the same general type, but its broad outline is distinct, and so is its sculpture in most of the specimens.

The specific name is derived from the locality of the type, Owl Canyon (noctuus=owl).

Occurrence: Lykins ranch, canyon west of Loveland, northwest of Loveland, Soldier Canyon, Cache la Poudre River, north of Bellvue, and Owl Canyon, Colo.

\section{Genus ANCHURA Conrad.}

Anchura kiowana Cragin?

Plate XLVIII, figures 6-8.

1895. Anchura kiowana Cragin, Colorado Coll. Studies, 5th year, pp. 66, 67 .

Cragin's original description is as follows:

Shell small, consisting of six convex whorls; spire elevated; suture impressed; wing of moderate size, consisting of a proximal flangelike part, continued posteriorly across half or more of the first spire whorl, and a carinated falciform process; carina gradually arising at the base of the falciform process and traversing the latter to the extremity; falciform process much shorter and less upturned distally than that of the somewhat similar species $A$. ruida White, not rising to the lowest level of the suture between the body whorl and the first spire whorl but having its point directed outward and somewhat upward so as to make a large angle with the axis of the spire, extero-inferior outline of wing rounded and the border between this and the canal sinuous, margin of upper (flange) part of wing describing a slightly concave to sigmoid outline and more or less thickened and reflexed; inner lip provided with a moderately broad and prominent callous; canal short and obliquely truncated; spire whorls and posterior half to two-thirds of body whorl ornamented with narrow curved, subvertical ribs or folds, of which there are about 24 on the first spire whorl, and with numerous revolving striae, the latter ornamentation gradually becoming prominent and superseding the ribs on the lowest third to half of the body whorl.

Height 19, breadth of body whorl, including excursion of the wing, 15 millimeters; angle of spire slopes about as in $A$. ruida White. * * * This species is distinguished from Anchura ruida White by the vertically costate body whorl, by the shorter, differently directed falciform process, and by having the alar carina confined directly to the wing and nearly to the falciform process instead of kcing common to the wing and part of the body whorl.

The writer has six specimens of a small species of Anchura, all poorly preserved but showing enough of the details to indicate a close relationship to $A$. Kiowana, as defined by Cragin's description and by good specimens. One specimen preserves a mold of the exterior of the wing, and although fine details are lacking it is clear that the wing has the form of that of A. Kiowana and that the carina is confined practically to the wing. The presence of vertical ribs is also indicated on the body whorl of this specimen. Another specimen preserving a mold of the spire and perhaps part of the body whorl shows a strong sculpture like that 
on A. Kiowana. The material available is inadequate for certain identification, but the differences from $A$. ruida White and other species of equivalent and adjacent formations and the resemblances to $A$. kiowana make a tentative assignment to that species justifiable

Occurrence: Kiowa shale of Kansas. Soldier Canyon, north of Bellvue, and Owl Canyon, Colo.

\section{Genus PACHYDISCUS Zittel. \\ Pachydiscus? sp. \\ Plate XLIX, figure 1.}

A single specimen of an ammonite, much weathered and preserving few details but suggesting strongly the genus Pachydiscus, is contained in the collections. It might well be a weathered specimen of $P$. brazoensis (Shumard), but it might equally well belong to some later species, and even a certain generic assignment must await better material.

The stratigraphic position of this specimen is a little higher than that of the remainder of the fossils described in this paper. It came from the upper sandstone of the "Dakota" hogback, above the dark shales, and not from the shales themselves, as did the other fossils.

Occurrence: Two miles southeast of Greenacre ranch, Colo.

Ammonite, genus and species undetermined.

Plate XLIX, figure 2.

A single small specimen of an ammonite preserving few distinctive features is contained in the collections. The shell is clearly that of a much compressed species with very small umbilicus and truncated but unchanneled venter. The earlier part of the shell preserved shows coarse, apparently rounded ribs, but the later part is practically smooth. The greatest diameter of the shell is 30 millimeters, and the width of the truncated venter a little more than 1 millimeter. The shell might be a species of Engonoceras, Knemiceras, Metoicoceras, or some other genus.

Occurrence: Iron Mountain, Wyo.

Fish scales and bones, undetermined.

Plate L, figures 1-11.

Fish scales and bones occur at several of the localities from which fossils are described in this paper. Some of them resemble Leuchichthyops vagans Cockerell, ${ }^{9}$ and others resemble Ichthyodectes sp. Cockerell. ${ }^{10}$ A few specimens are figured for the sake of more completely illustrating the known fauna.

Occurrence: Lykins Gulch, canyon west of Loveland, northwest of Loveland, Soldier Canyon, Cache la Poudre River, north of Bellvue, and Box Elder Creek, Colo.; Horse Creek and Iron Mountain, Wyo.

${ }^{9}$ Cockerell, T. D. A., Some American Cretaceous fish scales: U. S. Geol. Survey Prof. Paper 120, p. 180, pl. 35, figs. 1-15, 1919.

10 Idem, p. 179, pl. 34, figs, $3,4$. 


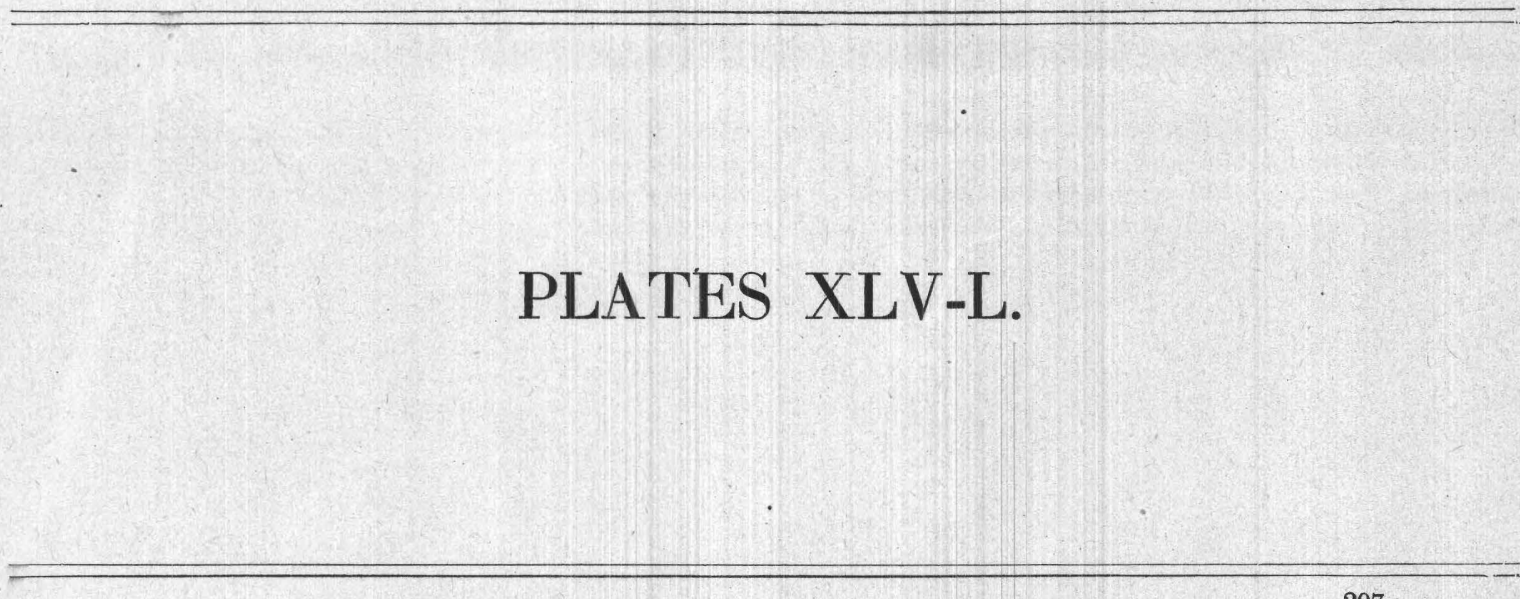



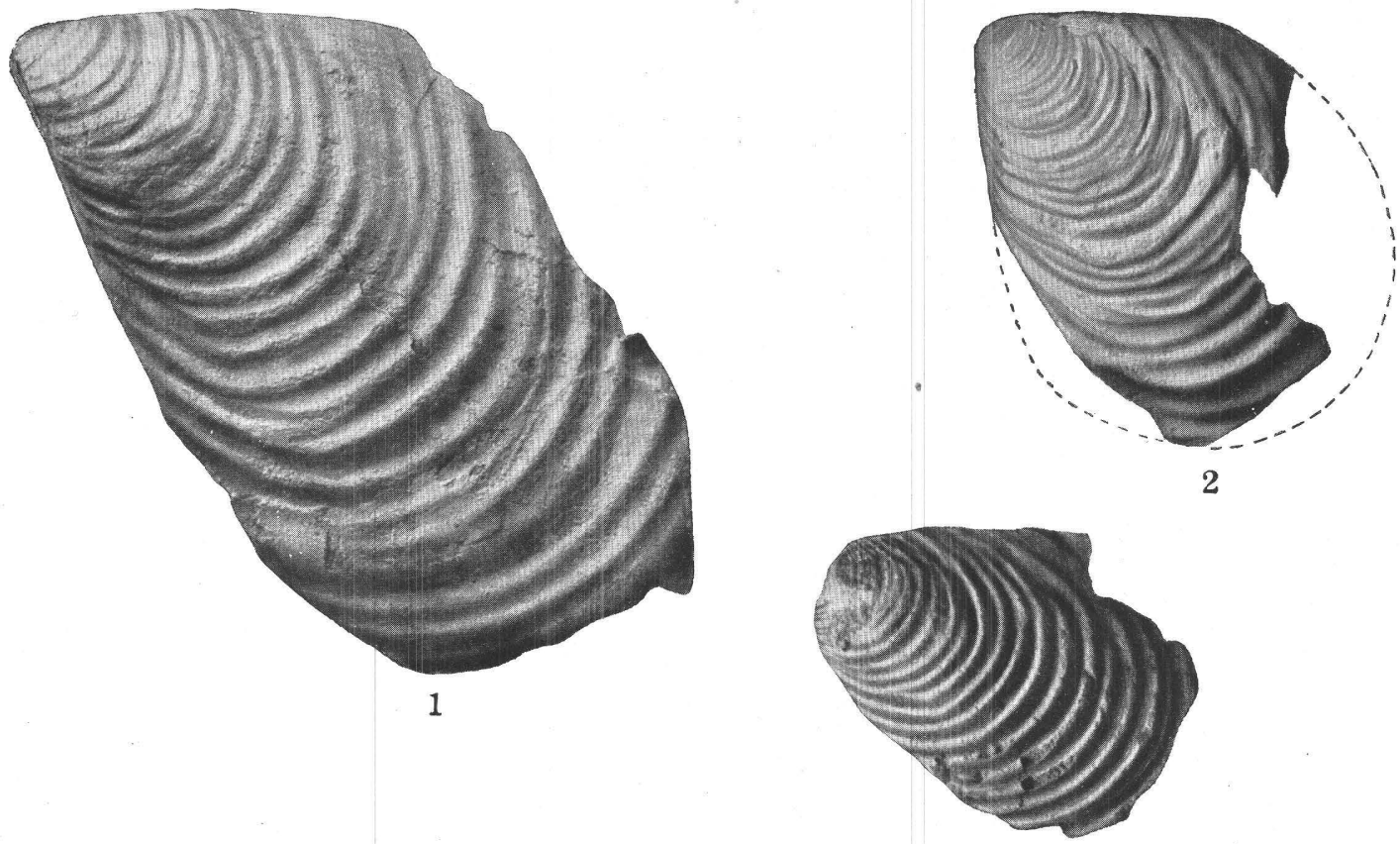

3
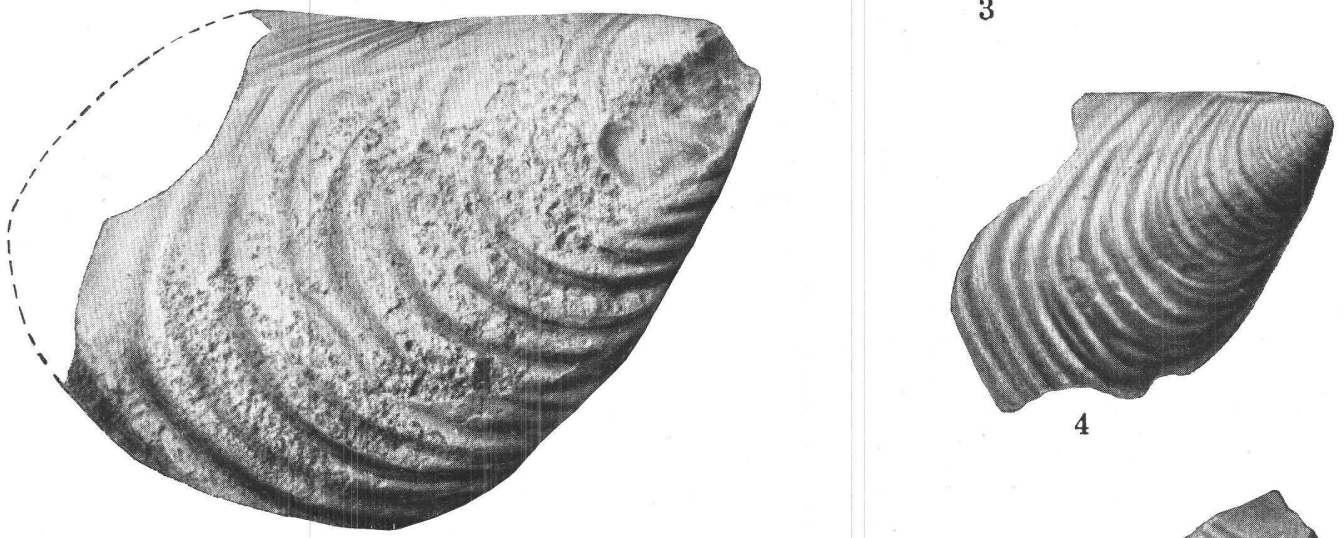

7
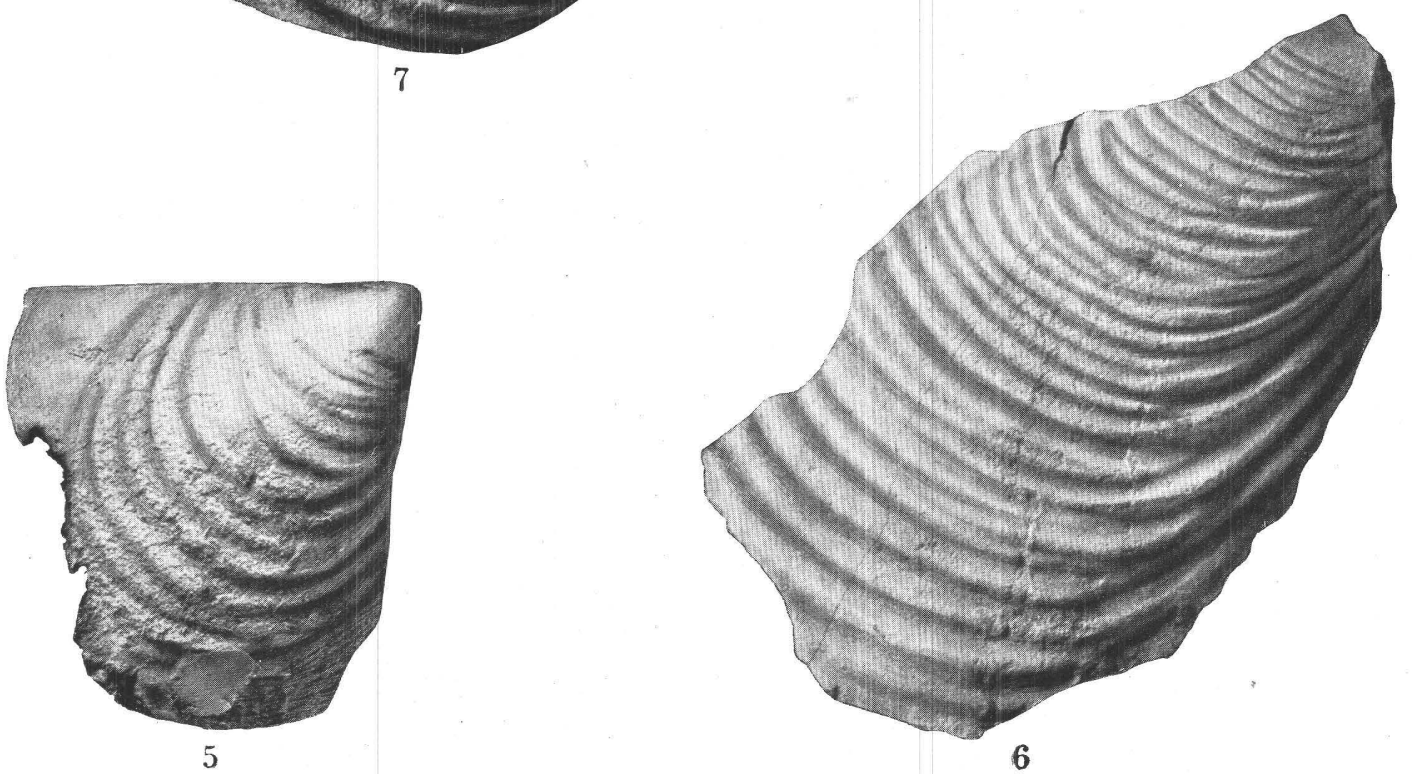

FOSSILS OF THE SO-CALLED DAKOTA FORMATION OF NORTHERN CENTRAL COLORADO AND SOUTHEASTERN WYOMING.

Inoceramus comancheanus Cragin, north of Bellvue, Colo, 1-3, Left valves of three specimens (U. S. Nat. Mus. catalog No. 32513); 4-\%. right valves of four specimens (U. S. Nat. Mus. catalog No. 32513). 
U. S. GEOLOGICAL SURVEY

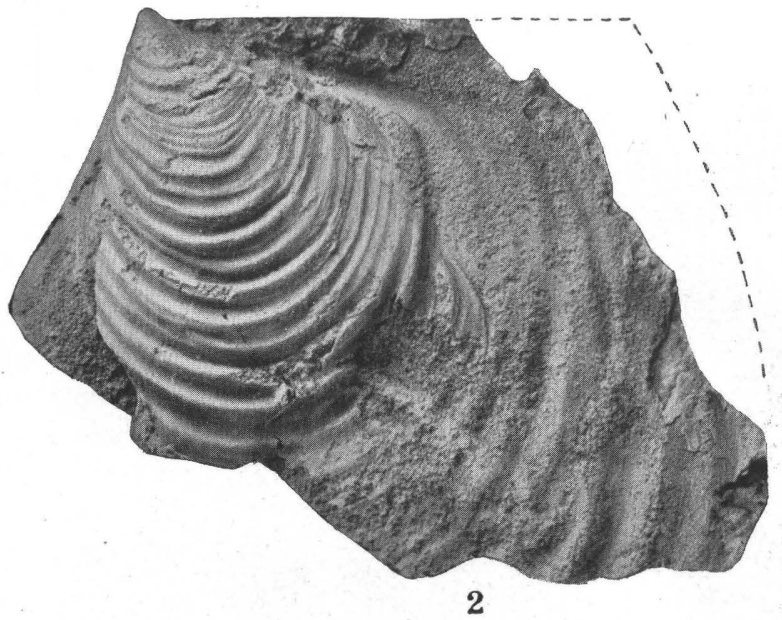

PROFESSIONAL PAPER 131 PLATE XLVI

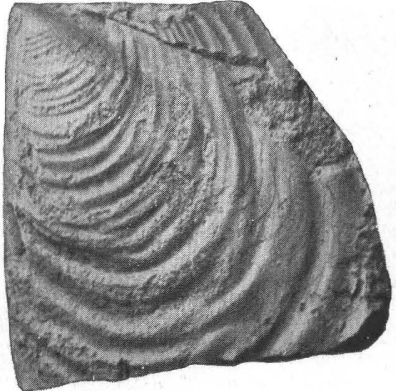

3

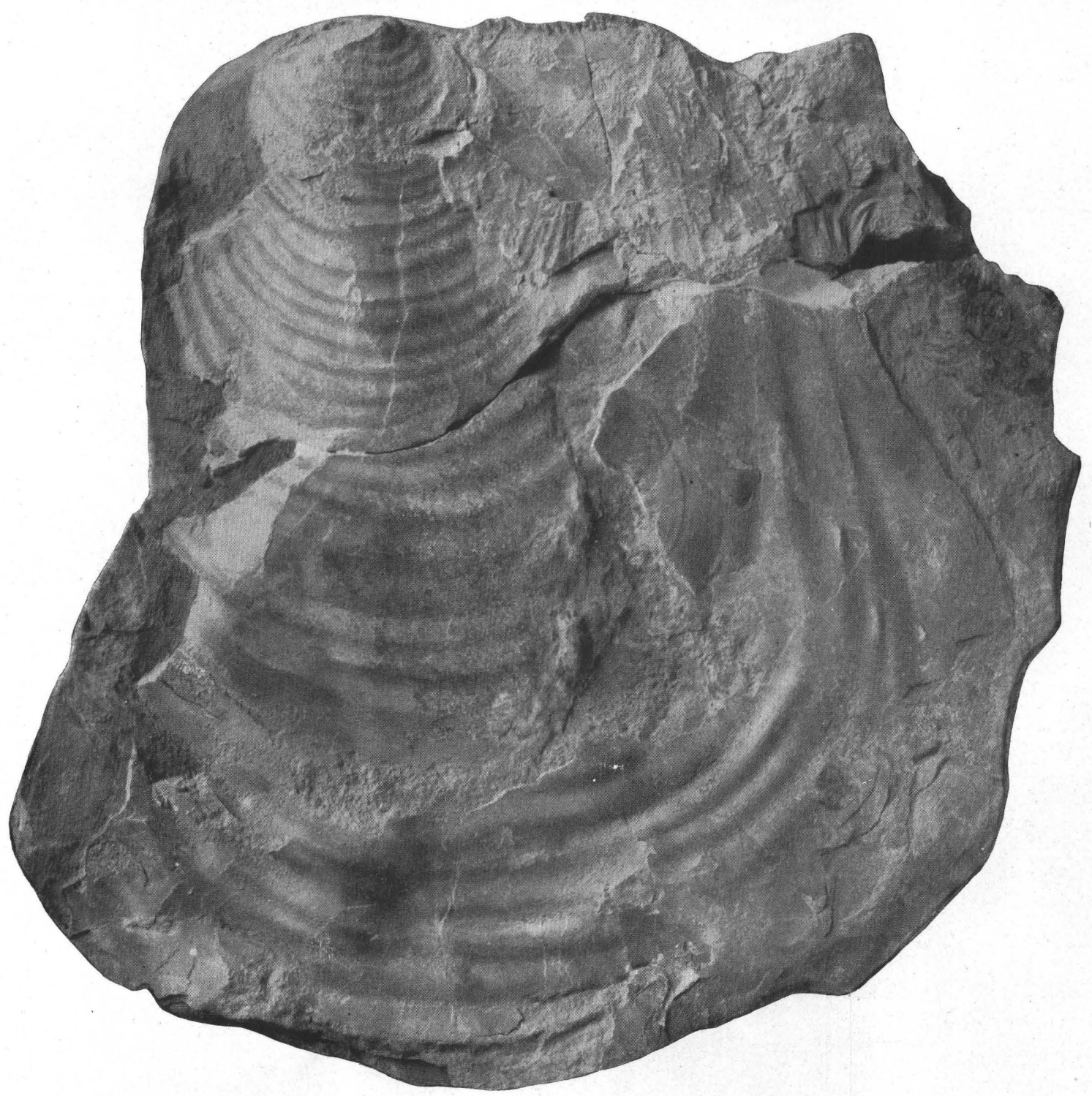

1

FOSSILS OF THE SO-CALLED DAKOTA FORMATION OF NORTHERN CENTRAL COLORADO AND SOUTHEASTERN WYOMING.

Inoceramus bellvuensis Reeside, n. sp., north of Bellvue, Colo. 1, Type specimen ( $\left.\times \frac{4}{5}\right)$, left valve (U. S. Nat. Mus, catalog No. 32514 ); 2, 3, left valves of two specimens (U. S. Nat. Mus. catalog No. 32515). 


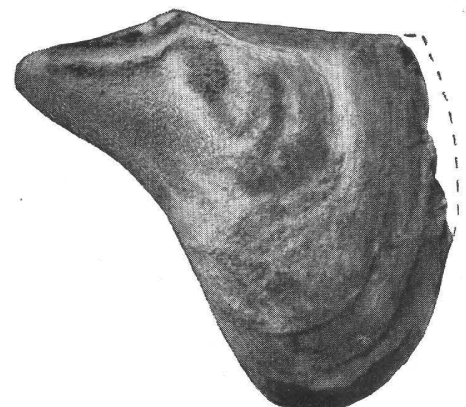

1

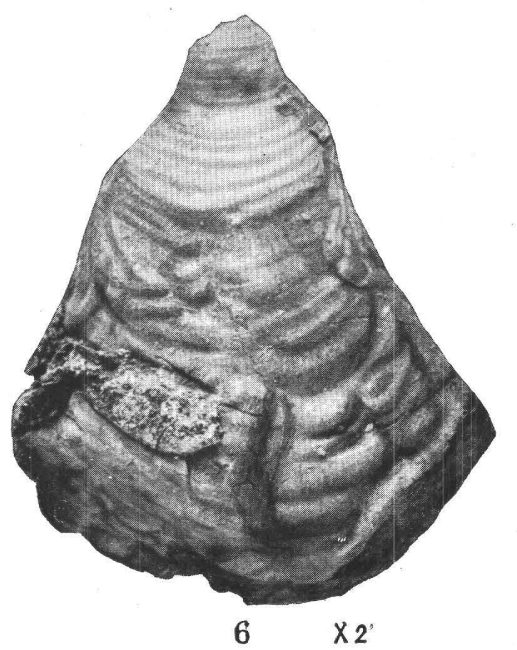

2
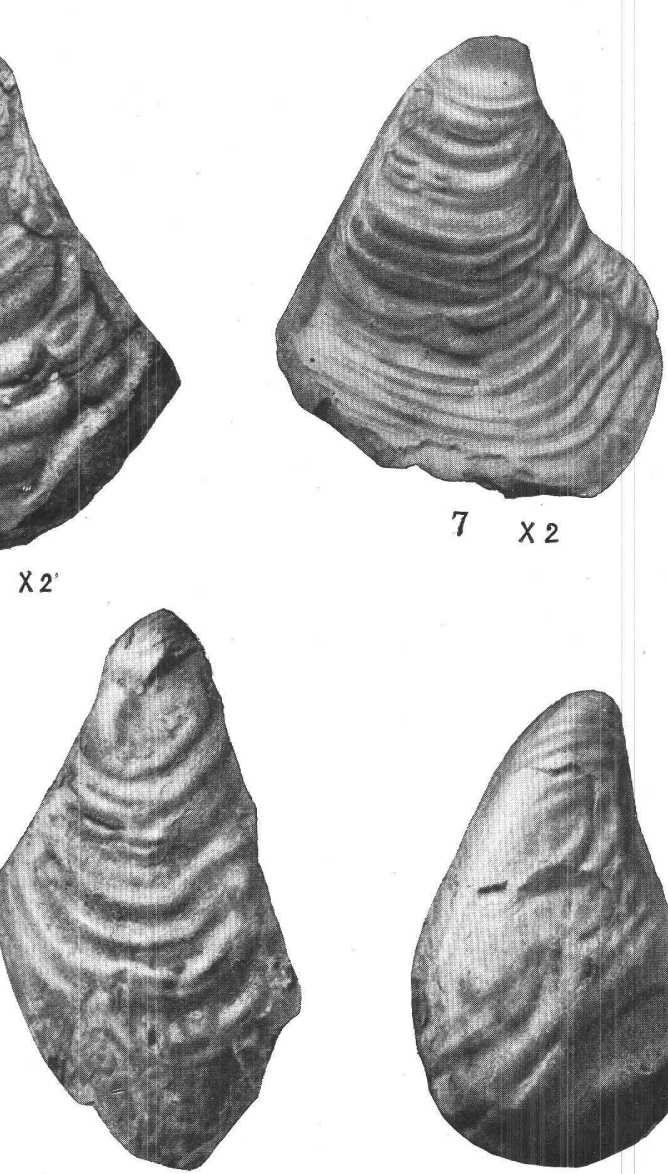

10

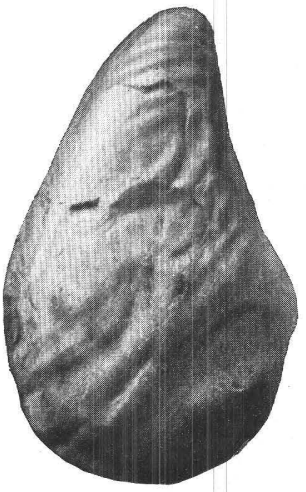

11

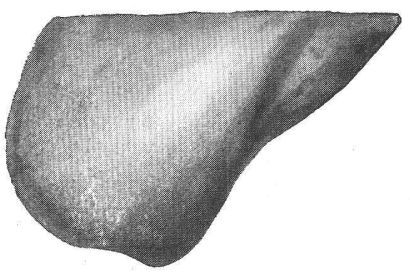

4

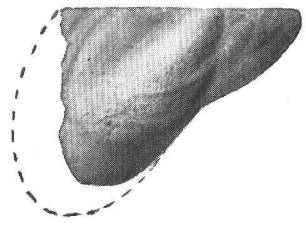

5

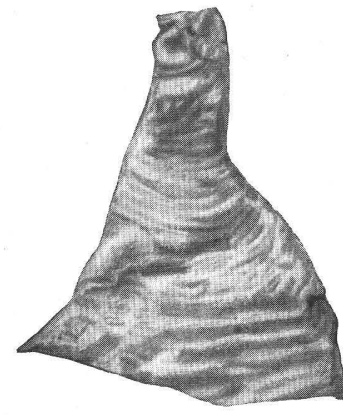

8

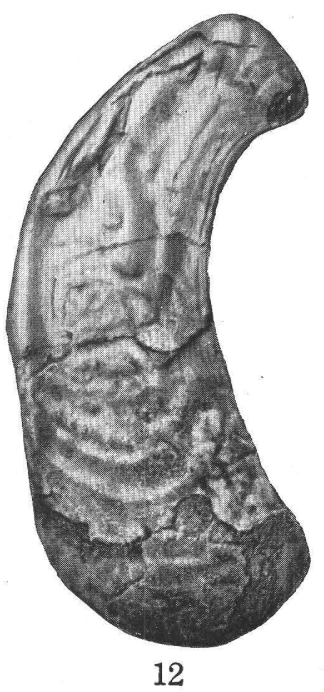

9

FOSSILS OF THE SO-CALLED DAKOTA FORMATION OF NORTHERN CENTRAL COLORADO AND SOUTHEASTERN WYOMING.

1-5. Pteria salinensis White, north of Bellvue, Colo. 1-3, Left valves of three specimens (U. S. Nat. Mus. catalog No. 32516); 4, 5, right valves of two specimens (U.S. Nat. Mus. catalog No. 32516).

6-10. Ostrea larimerensis Reeside, n. sp., Soldier Canyon, Colo. 6, Small complete valve, selected as the type (U. S. Nat. Mus. catalog No. 32517); 7,8 , apical part of two valves, showing the sculpture (U. S. Nat. Mus. catalog No. 32518); 9, 10, two larger specimens, partly exfoliated (U. S. Nat. Mus. catalog No. 32518).

11,12. Ostrea larimerensis Reeside, n. sp., north of Bellvue, Colo. 11, Internal cast of an unusually convex specimen (U. S. Nat. Mus. catalog No. 32519); 12, a nearly complete valve retaining the shell (U. S. Nat. Mus. catalog No. 32519 ). 

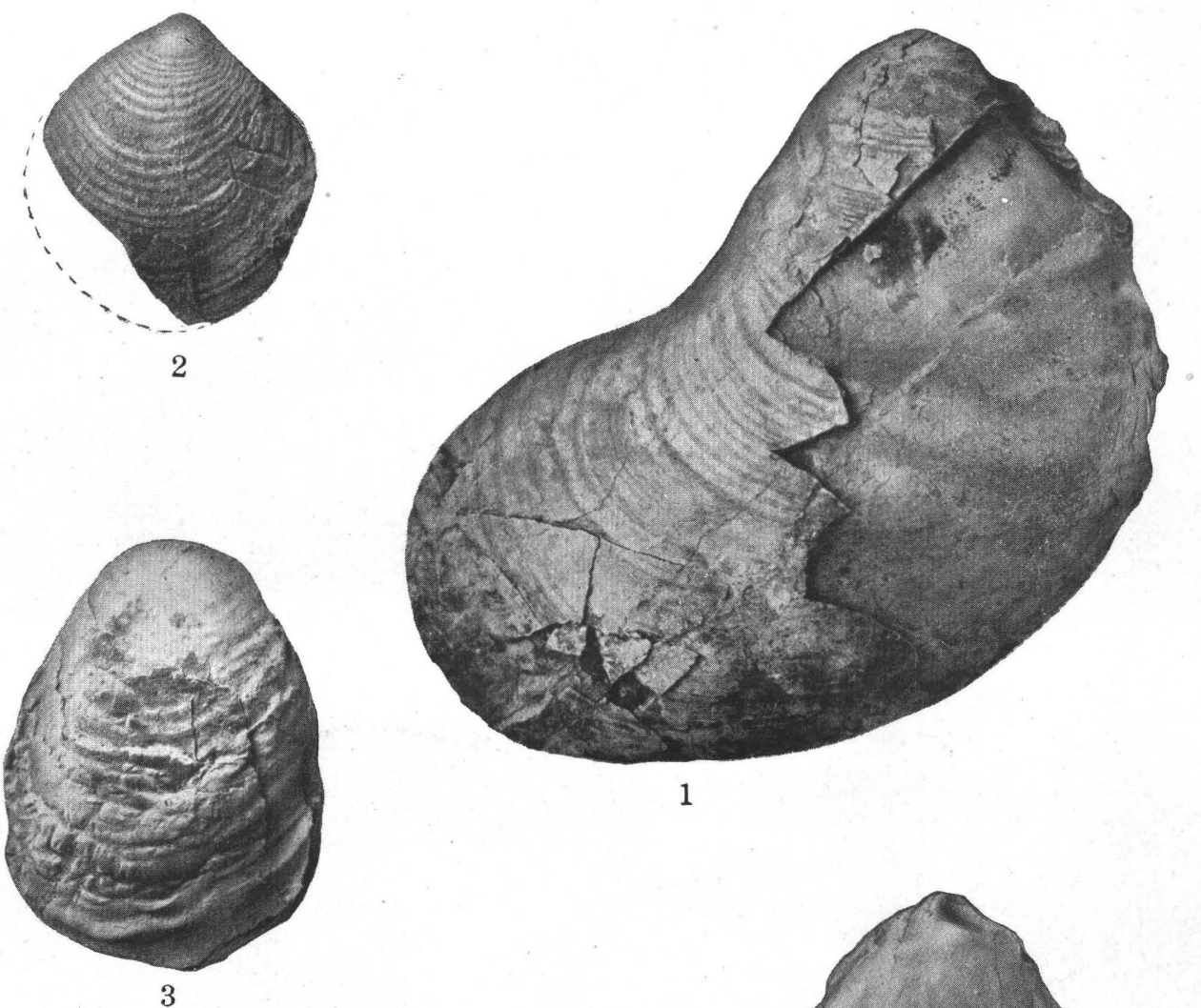

1

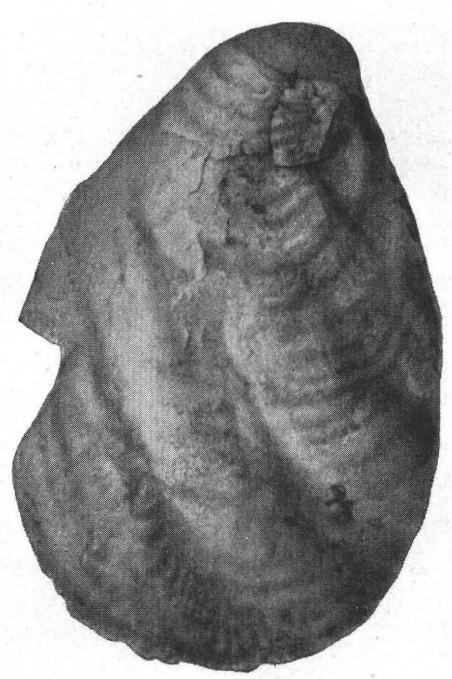

4

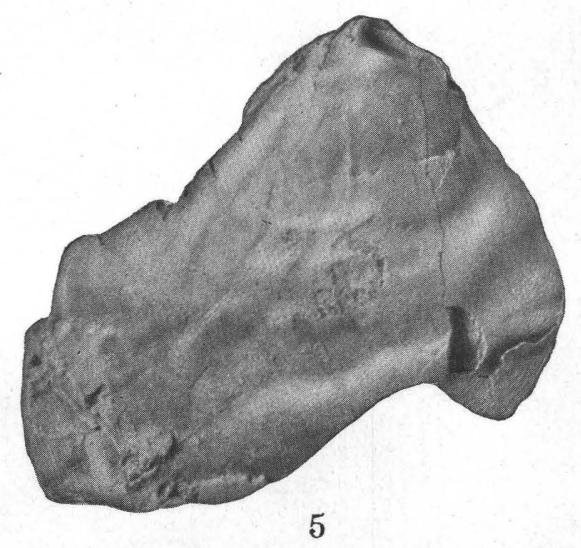

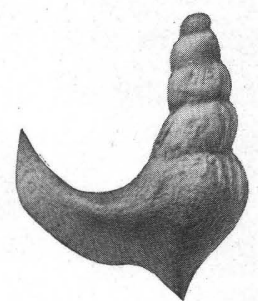

6

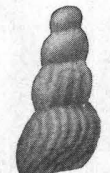

7

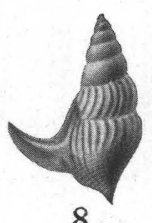

8

FOSSILS OF THE SO-CALLED DAKOTA FORMATION OF NORTHERN CENTRAL COLORADO AND SOUTHEASTERN WYOMING.

1, 2. Ostrea noctuensis Reeside, n. sp., Owl Canyon, Colo. 1, Type specimen (U. S. Nat. Mus. catalog No. 32520); 2 , Apical part of another specimen (U. S. Nat. Mus. catalog No. 32521).

3, 4. Ostrea noctuensis Reeside, n. sp., north of Bellvue, Colo. 3, Specimen retaining most of the shell (U. S. Nat. Mus. catalog No. 32522); 4, specimen retaining only the apical part of the shell (U. S. Nat. Mus. catalog No. 32522).

5. Ostrea noctuensis Reeside, n. sp., Soldier Canyon, Colo. Internal cast. (U. S. Nat. Mus. catalog No. 32523.)

6, 7. A nchura kiowana Cragin?, Soldier Canyon, Colo. Two specimens (X 2). (U. S. Nat. Mus. catalog No. 32524.)

8. A nchura kiowana Cragin; typical example from Kansas for comparison. 


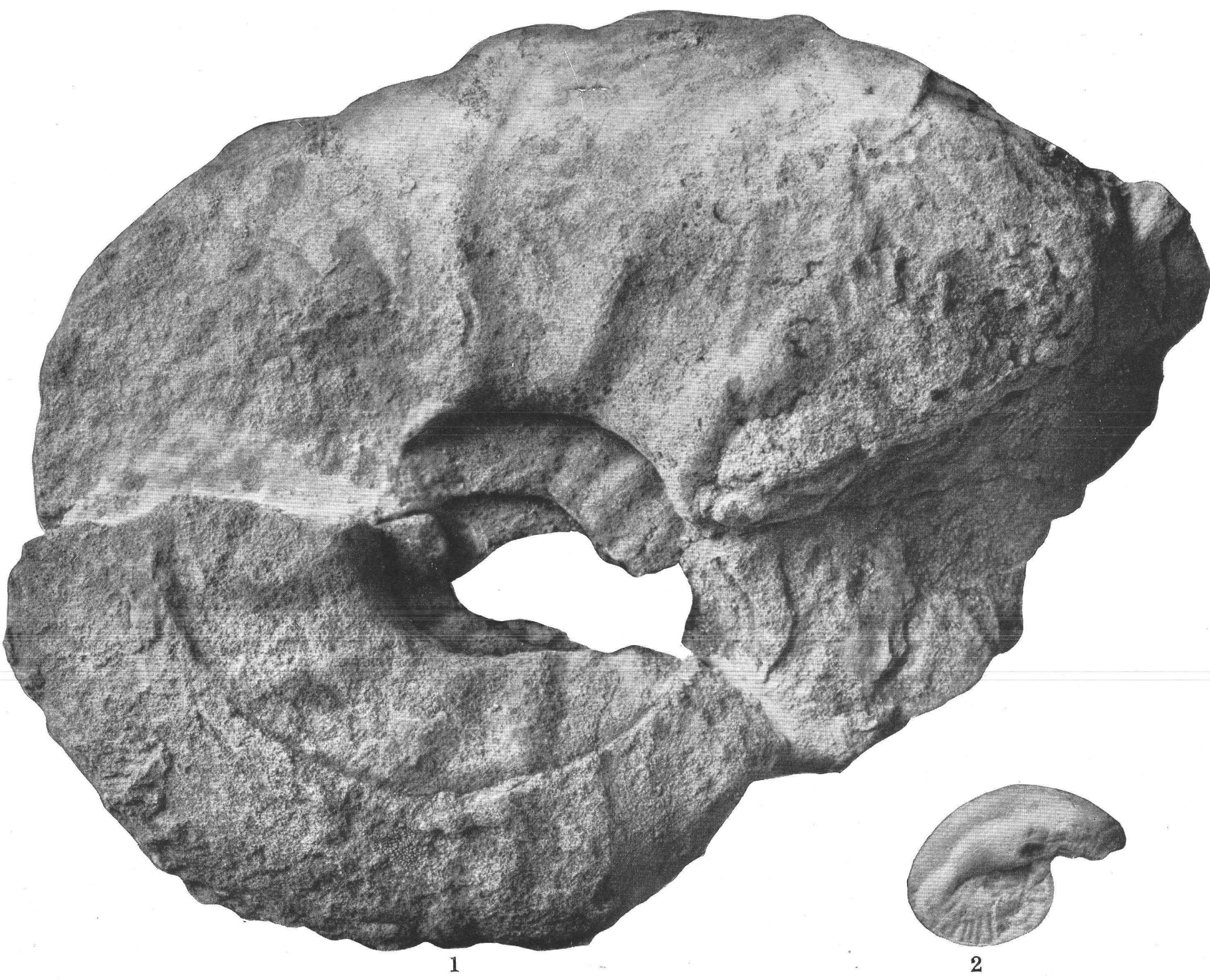

FOSSILS OF THE SO-CALLED DAKOTA SANDSTONE OF NORTHERN CENTRAL COLORADO AND SOUTHEASTERN WYOMING.

1. Pachydiscus? sp., 2 miles southeast of Greenacre ranch, Colo. (U. S. Nat. Mus. catalog No. 32525),

2. Ammonite, undetermined, Iron Mountain, Wyo. (U. S. Nat. Mus. catalog No. 32526). 
U. S. GEOLOGICAL SURVEY

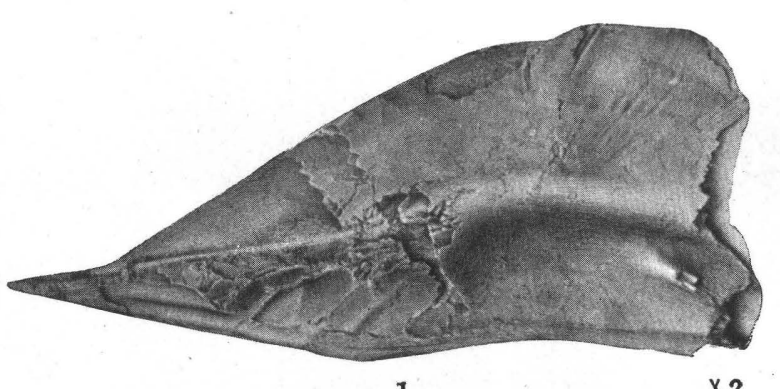

1

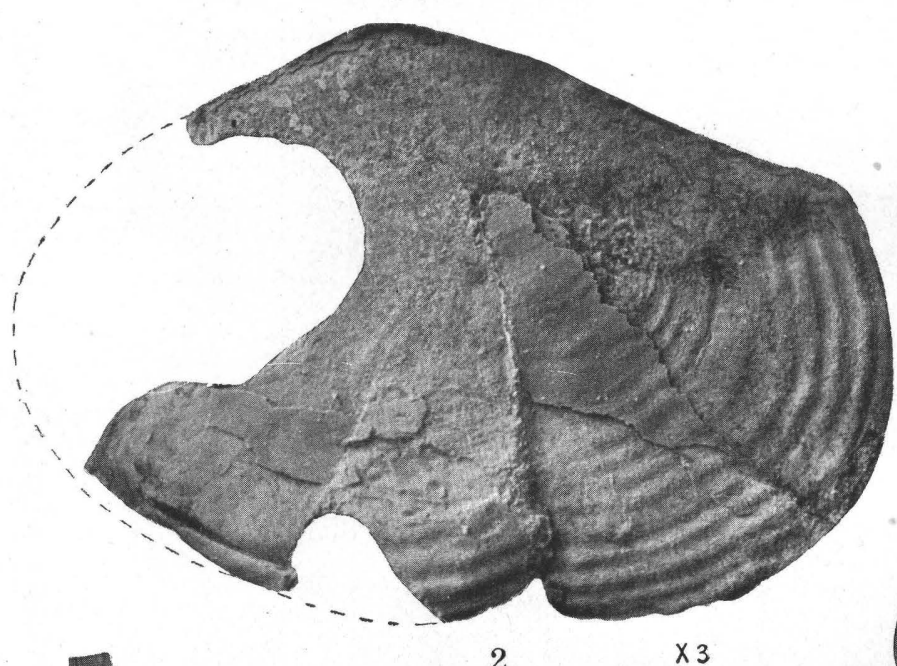

2
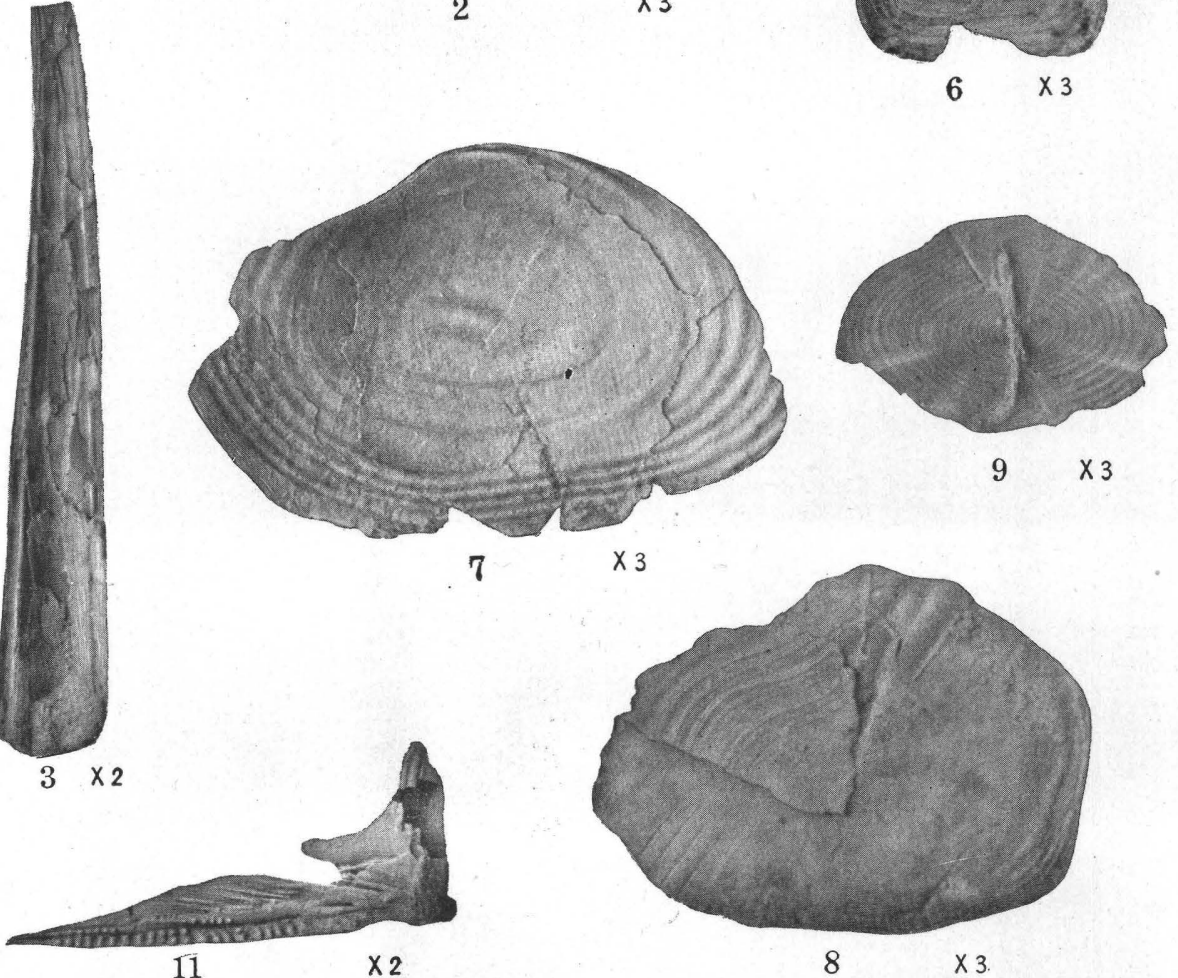

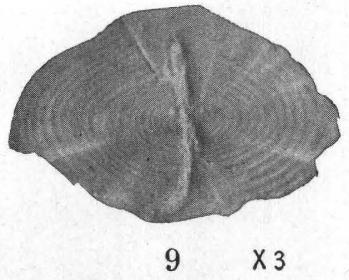

PROFESSIONAL PAPER 131 PLATE L

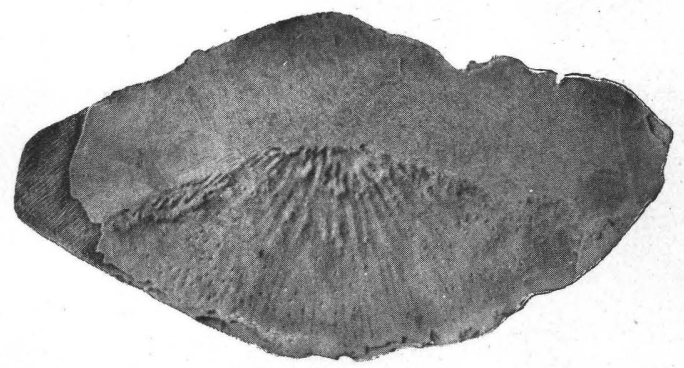

$X 3$

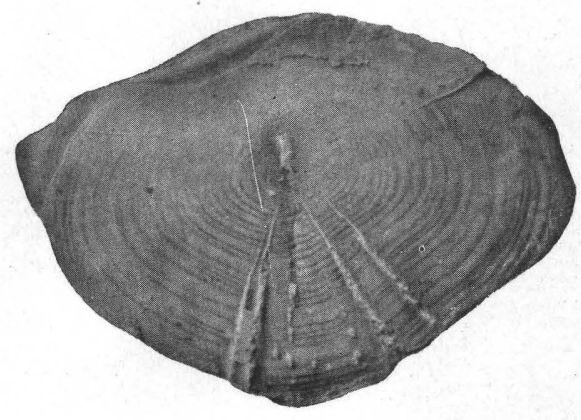

5

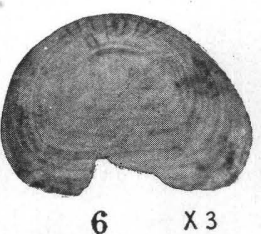

$\times 3$

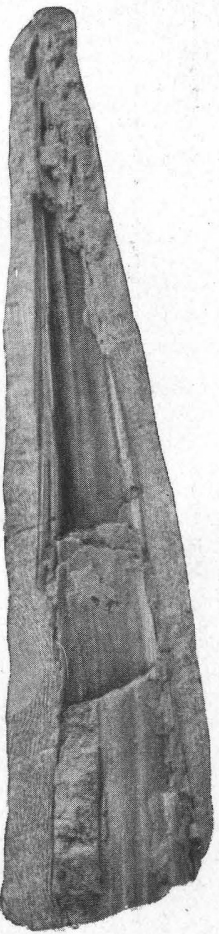

10

FOSSILS OF THE SO-CALLED DAKOTA SANDSTONE OF NORTHERN CENTRAL COLORADO AND SOUTHEASTERN WYOMING.

1-\%. Fish scales and bones, north of Bellvue, Colo. (U. S. Nat. Mus. catalog No. 10771)

8-10. Fish scales and bone, Iron Mountain, Wyo. (U. S. Nat. Mus. catalog No. 10772).

11. Fish bone, Horse Creek, Wyo. (U. S. Nat. Mus. catalog No. 10773). 